\title{
The Spirit throughout the Canon
}

\section{A Survey of Biblical Authors' Approaches to the Divine Spirit}

\author{
Craig S. Keener | ORCID: 0000-0003-3430-1998 \\ Asbury Theological Seminary, Wilmore, Kentucky, USA \\ craig.keener@asburyseminary.edu
}

I am grateful to Bill Oliverio and Nimi Wariboko for inviting me to guest edit this issue of Pneuma. Although I helped design it, Bill carried the largest share of organizational work. Our biggest thanks go to our authors, some of whose labors, especially on longer essays, were extensive. The space allotted to various authors is not meant to reflect differing levels of respect for different parts of the canon. Word counts were assigned based especially on the proportion of references to the Spirit in various books or sections of the canon, thus with larger word counts for the New Testament than the Old Testament, and for works such as Luke-Acts than 1-2 Thessalonians.

Contributors here resemble a veritable "who's who" among pentecostal biblical scholars, though the list of the "who's who" members of this guild could have been extended, and I offer apologies to scholars who were not included. Whereas a generation ago the number of pentecostal biblical scholars was limited, and those well known outside pentecostal circles was even smaller, today there are more than this issue had room to showcase, both in North America and in parts of the world where Pentecostalism is stronger numerically.

Our initial list included more names than we could use, and past editorial experience suggested that many busy scholars would decline. Instead, to our surprise, nearly everyone we initially invited to participate in the project agreed to do so and fulfilled their commitments. Many others, however, participated in the double-blind review process, with two reviewers per essay plus myself. The editors were reticent to list the issue's large review team because of understandable confidentiality concerns, but these scholars merit much gratitude for their extensive work.

Participating scholars reflect a range of perspectives and backgrounds. On average, this work offers mainstream pentecostal scholarship, but we reflect a range of historical and literary approaches, and we welcomed and expected all contributors to contribute from their own areas and approaches of strength. 
In the following survey, I note merely some of the points highlighted in the following essays, in an attempt to show the continuity of many themes. Although most, probably all, of our authors would affirm the divine Personhood of the Spirit, our inductive focus on most parts of the biblical canon leads to a stress on empowerment, whether for life, worship, or ministry for God.

In the Old Testament, the Spirit acts as divine agency and empowers God's people. Michael Brown and Roger Cotton address God's ruach in the Pentateuch, with observations that include the Spirit's activity in creation and empowerment for leadership, prophecy, and artistry. Brian Neil Peterson explores God's Spirit in earlier narrative works about Israel in the land, emphasizing prophetic inspiration and miraculous empowerment. Emma Austin and Jacqueline Grey discuss God's Spirit in postexilic narratives, including the Spirit's role in worship. Lee Roy Martin addresses God's Spirit as agent of God's life-giving power in the Psalms. Wonsuk Ma discusses the Spirit empowering God's chosen people in Isaiah. Alicia R. Jackson addresses the Spirit as God's presence also involved in restoring and transforming God's people. Rick Wadholm discusses the Spirit's role as life, witness, judge, and gift in Daniel and the so-called Minor Prophets.

Most of the Spirit's activity described in New Testament books flows naturally from the Spirit's activities already evident from the varied essays on sections of the Old Testament canon. Blaine Charette addresses Matthew's distinctive depiction of the Spirit, including in relation to the kingdom, and addresses the Spirit's empowerment to face suffering in Mark. Robert Menzies explores especially the dimension of prophetic empowerment in the pneumatology of Luke-Acts. John Christopher Thomas treats this and other aspects of the Spirit's work in the Gospel and Epistles of John.

These observations continue in the epistles. Finny Philip addresses God's gift of the Spirit to Gentiles in Paul's letter to the Romans, as also Roji Thomas George does in Galatians. Ayodeji Adewuya explores the Spirit's role in the lives and worship of believers in 1 Corinthians. Jacob Cherian and Joe Thomas address the Spirit as seal, deposit, mark of the new covenant, and member of the Trinity in 2 Corinthians. Dan Darko discusses the Spirit's role in Ephesians and Philippians, Holly Beers the Spirit's role in Colossians and Philemon, and Roji Thomas George the Spirit's role in 1-2 Thessalonians. Kenneth Archer explores the Spirit's trinitarian role in salvation, holiness, and empowerment in the Pastorals. Cynthia Westfall addresses the Spirit's work, including in speaking in and through Scripture, in Hebrews. Rebecca Skaggs discusses the Spirit's varied activities, including transformation and от prophecy, in the Petrine epistles and Jude. 
Finally, Melissa Archer and Robby Waddell skillfully address the Spirit in John's Apocalypse, including the Spirit's role in inspiring prophecy.

\section{$2 \quad$ Synthesis}

The Spirit often empowered prophets and leaders in the Old Testament (for example, Num 11:17, 24-30; Judg 3:10; 1Sam 19:20-24), and such empowerment, which Moses desired for God's people (Num 11:29), would also mark the promised time of future restoration (Joel 2:28-29 [MT 3:1-2]). Less commonly, we read of the promise of eschatological spiritual transformation (Ezek 36:2427), related to the Spirit's role giving life (Ezek 37:1-14) and perhaps also in creation (Gen 1:2; Ps 104:30). Both these prominent motifs also flourished in early Judaism, although the latter motif (of spiritual transformation) seems to have flourished in a more limited circle, especially among Essene or related movements.

Not surprisingly, then, these motifs resurface in a variety of ways in the NT, which depicts an already/not yet eschatological fulfillment. The Spirit both transforms (as in John 3:5-8, echoing Ezek 36:25-27; 37:9, 14) and empowers (for example, Acts 2:17-18, adapting Joel 2:28-29). To Paul, for example, everything in the Christian life-salvation, ethics (the fruit of the Spirit), ministry to others (by gifts of the Spirit), and so forth comes from the Spirit-from dependence on God. The essence of the Christian life, as Gordon Fee so copiously documented in his now classic God's Empowering Presence, ${ }^{1}$ is life in and by the Spirit. Moreover, just as God's Spirit marks the restored, eschatological people of God in the Old Testament prophets, Paul, Luke, and some other New Testament writers highlight the Spirit's work among Gentile believers as a sign that Gentiles who embrace Israel's king are grafted into the covenant people.

1 Gordon D. Fee, God's Empowering Presence: The Holy Spirit in the Letters of Paul (Grand Rapids, MI: Baker Academic, 2009). 